\title{
Measurement of total dissolved phosphorus in small volumes of iron rich interstitial water
}

\author{
René Gächter ${ }^{1}$, André Tessier ${ }^{2}$, Erno Szabo ${ }^{3}$ and Richard Carignan ${ }^{2}$ \\ 1 Institute of Aquatic Sciences (EAWAG), Swiss Federal Institute of Technology (ETH), \\ CH 6747 Kastanienbaum, Switzerland \\ 2 INRS-Eau, Université du Québec, C.P. 7400, Sainte-Foy, Québec, Canada GIV 4C7 \\ ${ }^{3}$ Swiss Federal Institute for Water Resources and Water Pollution Control (EAWAG), \\ $\mathrm{CH}-8600$ Dübendorf, Switzerland
}

Key words: Sediment; interstitial water; phosphorus; iron; persulfate digestion.

\begin{abstract}
It is shown that sorption of orthophosphate to iron compounds, formed during persulfate digestion, can cause a significant underestimation of total dissolved phosphorus in interstitial waters rich in iron and poor in phosphorus. Labelling the samples with carrier free ${ }^{32} \mathrm{PO}_{4}$ before digestion allows to correct for these losses.
\end{abstract}

\section{Introduction}

Sediment phosphorus $(\mathrm{P})$ exists in a variety of inorganic and organic species which are either dissolved in the interstitial water, adsorbed to particle surfaces or incorporated into organisms and remains of organisms and mineral phases. Dissolved $P$ compounds present in sediments are usually separated from particulate $P$ by centrifugation, filtration or dialysis (Löfgren, 1987). According to Enell et al. (1987), most porewater investigations have focused on the analysis of dissolved reactive $P$ (SRP) and almost no information exists on total dissolved P(TDP) in interstitial water. It is often assumed that inorganic phosphates are the dominant $P$ species in interstitial water. However, a significant fraction of the phosphorus may be released in organic form from lake sediments rich in organic material as demonstrated by Boers et al. (1985). Obviously, in such cases, the P cycling cannot be understood if dissolved organic $\mathrm{P}$ is disregarded.

Methods to measure low concentrations of TDP in porewater must often be adapted to small sample volumes, especially if sampling is performed by in-situ dialysis (Hesslein 1976). Digestion of dissolved organic compounds with potassium persulfate, followed by a colorimetric $\mathrm{P}$ determination with an autoanalyzer, as described by Vogler (1965), is a well-established limnological method to determine TDP (e.g. Holdren and Armstrong 1980; Löfgren 1987; Stauffer and Armstrong 1986; Ostrofsky et al. 1989; Sondergaard 1989). We have found, however, that an 
iron precipitate, presumably jarosite, forms during digestion of iron rich anoxic porewaters. After digestion of the samples the $\mathrm{pH}$ is 2.3 , and large concentrations of sulfate are present. Under these conditions, thermodynamic calculations predicts the formation of a jarosite (e.g. $\mathrm{KFe}_{3}\left(\mathrm{SO}_{4}\right)_{2}(\mathrm{OH})_{6}$; Chapman et al. 1983) which should precipitate the oxidized iron. This solid interfered with the colorimetric determination of TDP by absorption and scattering of light and/or by inhibition of the developement of the molybdenum blue complex. Removal of the iron precipitate prior to the colorimetric analysis led to a severe underestimation of TDP since sorption of phosphates on metal oxyhydroxides is favored at low pH (Stumm and Morgan 1981). To correct for these sorption losses we describe an isotopic dilution method.

\section{Methods}

Interstitial water samples were obtained by centrifugation and subsequent filtration $(0.45 \mu \mathrm{m})$ of anoxic sediments sampled in late October 1990 in the deepest bassin of Lac Tantaré, an oligotrophic lake, situated north of Québec City $\left(47^{\circ} 04^{\prime} \mathrm{N}, 71^{\circ} 32^{\prime} \mathrm{W}\right)$. In this lake, chlorophyll concentrations are $<1 \mu \mathrm{g} / \mathrm{L}$ and oxygen is progressively depleted in the bottom water during winter and summer stratification periods to 2$3 \mathrm{mg} / \mathrm{L}$. The sediments are highly organic (up to $65 \%$ loss of dry weight during ignition at $550^{\circ} \mathrm{C}$ ), and porous (porosity of $0.94-0.98$ for the top $10 \mathrm{~cm}$; Carignan 1988). Typical peak concentrations of dissolved iron found in the interstitial waters of Lac Tantaré vary between 100 and $270 \mu \mathrm{mole} / \mathrm{L}$, depending on the sampling location.

\section{Principle}

Prior to digestion, interstitial water samples were labelled with a known amount of carrier free ${ }^{32} \mathrm{PO}_{4}\left({ }^{32} \mathrm{P}_{\text {added }}\right)$. After digestion, the samples were centrifuged and TDP concentrations ([TDP $\left.\left.{ }_{\text {cent }}\right]\right)$ and ${ }^{32} \mathrm{P}$ activities $\left({ }^{32} \mathrm{P}_{\text {cent }}\right)$ were determined in the supernatants. Uniform labelling of the total $\mathrm{P}\left(\mathrm{TP}=\mathrm{TDP}_{\text {cent }}+\mathrm{P}\right.$ associated with the precipitated iron) in the samples is expected since after digestion very likely all $P$ is present as inorganic species. From these considerations it follows that:

$$
\left[\mathrm{TDP}_{\text {cent }}\right] /[\mathrm{TP}]=\left({ }^{32} \mathrm{P}_{\text {cent }}\right) /\left({ }^{32} \mathrm{P}_{\text {added }}\right)
$$

Since all $\mathrm{P}$ present in the sample, was operationally defined as dissolved prior to digestion, [TP] after digestion equals [TDP] before digestion. Therefore, [TDP] of the original sample can be determined by solving eq(1) for [TP]:

$$
[\mathrm{TDP}]=[\mathrm{TP}]=\left[\mathrm{TDP} \mathrm{cent}_{\text {en }}\right]\left({ }^{32} \mathrm{P}_{\text {added }}\right) /\left({ }^{32} \mathrm{P}_{\text {cent }}\right)
$$

\section{Analytical procedure}

All water used was deionized and filtered (Millipore $0.2 \mu \mathrm{m}$ nominal pore size). Use of detergents was avoided and all glassware were soaked in $10 \% \mathrm{HCl}$ and carefully rinsed. 
Small volumes $(4.5 \mathrm{ml})$ of samples or standards (solutions of $\mathrm{KH}_{2} \mathrm{PO}_{4}$ ) were pipetted into centrifugation vials (borosilicate tubes $13 \mathrm{~mm} \times 100 \mathrm{~mm}$ with screw caps). Additions of $150 \mu \mathrm{l}$ of $5 \% \mathrm{~K}_{2} \mathrm{~S}_{2} \mathrm{O}_{8}$ were made and $100 \mu \mathrm{l}$ of a diluted carrier free ${ }^{32} \mathrm{PO}_{4}$ solution (Amersham Canada Ltd.) were added to obtain an activity of approximately $500 \mathrm{cpm}$ and the tubes were covered with aluminum foil, closed with screw caps and autoclaved at $120^{\circ} \mathrm{C}$ for $2 \mathrm{~h}$. If necessary, after digestion, sample volumes were readjusted to $4.75 \mathrm{ml}$ (marked on centrifugation vial) with water to compensate for losses due to evaporation. Then, the precipitates were separated from solution by centrifugation and the supernatants were transfered to scintillation vials. ${ }^{32} \mathrm{P}$ activity $\left({ }^{32} \mathrm{P}_{\text {cent }}\right)$ was determined in a liquid scintillation spectrometer by Cerenkov counting. Because determination of ${ }^{32} \mathrm{P}$ activity by this technique is performed without the addition of chemicals, the same sample can be used to determine $\left[\mathrm{TDP}_{\text {cent }}\right]$ by the colorimetric method afterwards.

In order to optimize the sensitivity of the automated colorimetric method, the ratio of sample to reagent volumes was minimized. Fig. 1 shows the autoanalyzer manifold.

The "Reagent" comprises $20 \mathrm{ml}$ of ammonium molybdate solution, $5 \mathrm{ml}$ of ascorbic acid solution and $0.05 \mathrm{ml}$ of a wetting agent (Levor IV or Alpkem Ultra Wet $60 \mathrm{~L})$. Fresh reagent should be prepared every day.

Ammonium molybdate solution: In a $1000 \mathrm{ml}$ volumetric flask, dissolve $144 \mathrm{ml}$ of $\mathrm{H}_{2} \mathrm{SO}_{4}$ in $300 \mathrm{ml}$ of water. Add $10 \mathrm{~g}$ of amido sulfuric acid $\left(\mathrm{H}_{2} \mathrm{NSO}_{3} \mathrm{H}\right)$ dissolved in $100 \mathrm{ml}$ of water, $12.5 \mathrm{~g}$ of ammonium molybdate $\left(\left(\mathrm{NH}_{4}\right)_{6} \mathrm{Mo}_{7} \mathrm{O}_{24} \cdot 4 \mathrm{H}_{2} \mathrm{O}\right)$ dissolved in $200 \mathrm{ml}$ of water and $0.3428 \mathrm{~g}$ of potassium antimony oxide tartarate $\left(\mathrm{K}(\mathrm{SbO}) \mathrm{C}_{4} \mathrm{H}_{4} \mathrm{O}_{6} \cdot 0.5 \mathrm{H}_{2} \mathrm{O}\right)$ dissolved in $200 \mathrm{ml}$ of water. Fill up with water to $1000 \mathrm{ml}$. The resulting solution must be clear and colourless.

Ascorbic acid solution: Dissolve $25 \mathrm{~g}$ of $\mathrm{L}(+)$ Ascorbic acid $\left(\mathrm{C}_{6} \mathrm{H}_{6} \mathrm{O}_{6}\right)$ in $250 \mathrm{ml}$ of water. This solution is stored in the refrigerator in a dark bottle.

Wetting agent or "Diluent" consists of $0.05 \mathrm{ml}$ of wetting agent (Levor IV or Alpkem Ultrawet $60 \mathrm{~L}$ ) diluted with $25 \mathrm{ml}$ of water. It should be prepared daily.

Before starting the measurements, the autoanalyzer system needs to be rinsed first with a fresh solution containing $20 \mathrm{ml}$ of $1 \mathrm{~N} \mathrm{NaOH}$ and $2 \mathrm{ml}$ of $34 \% \mathrm{H}_{2} \mathrm{O}_{2}$ and then with $20 \mathrm{ml}$ of $0.25 \mathrm{M} \mathrm{H}_{2} \mathrm{SO}_{4}$. Afterwards, water, diluent and reagent are pumped through the system, until the baseline remains stable.

In order to determine the concentration of iron precipitated during sample digestion, the solids remaining in the centrifugation tubes after removing the supernatants were dissolved with $0.5 \mathrm{ml}$ of a solution of saturated hydroxylamine hydrochloride $\left(\mathrm{NH}_{2} \mathrm{OH} \cdot \mathrm{HCl}, \mathrm{pH}=2\right)$ at a temperature of $70^{\circ} \mathrm{C}$. The dissolved iron concentration was measured by flame atomic absorption spectrophotometry (Varian AA-20). 


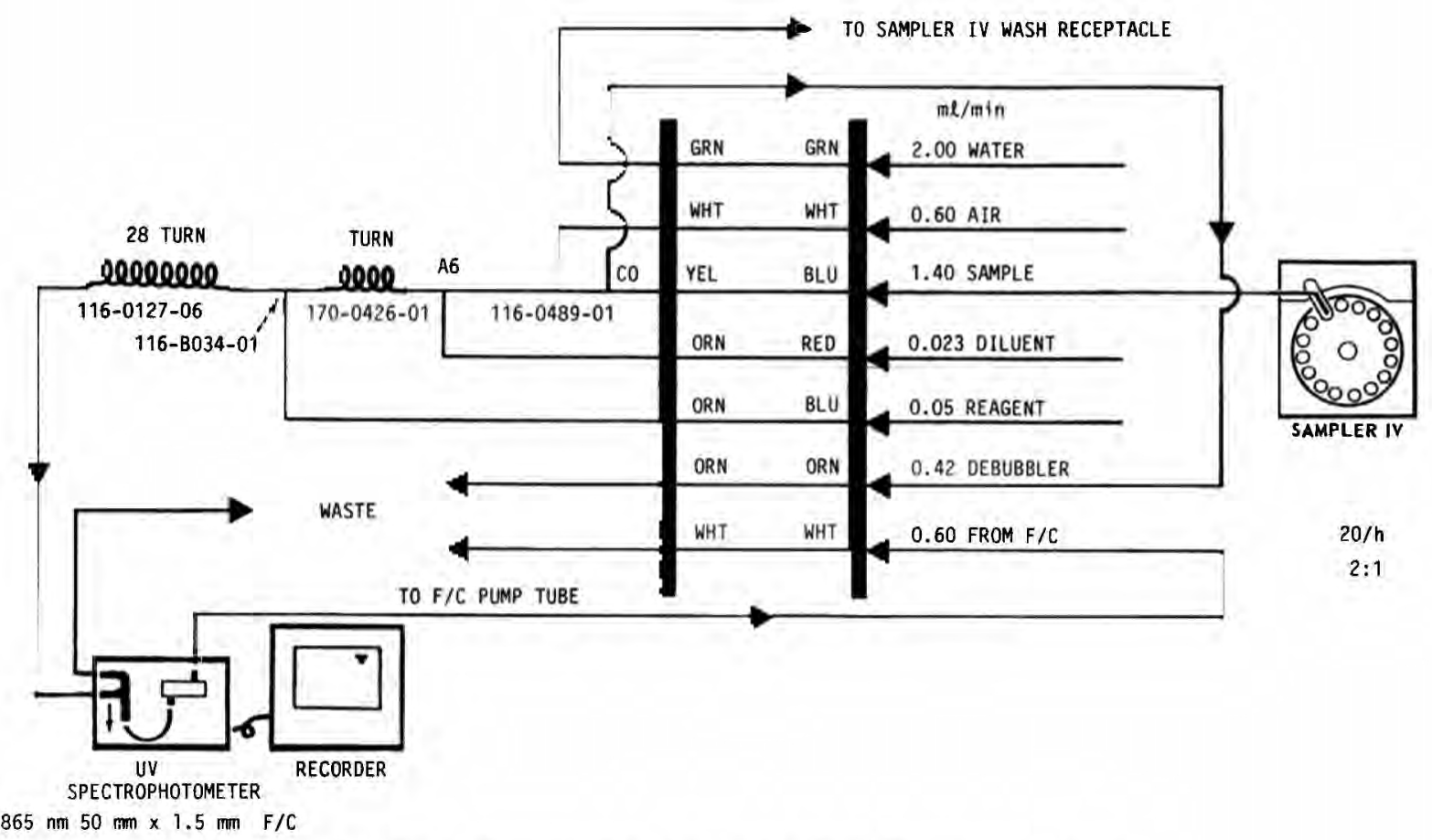

Figure 1. Autoanalyzer manifold for the determination of orthophosphate. Figures and abbreviations are Technicon part numbers 


\section{Results and discussion}

According to eq (2) the ratio $\left({ }^{32} \mathrm{P}_{\text {cent }}\right) /\left({ }^{32} \mathrm{P}_{\text {added }}\right)$ indicates the relative concentration of $P$ remaining in solution after digestion. Iron-free $P$ standards did not loose ${ }^{32} P$ activity during digestion and centrifugation and hence this ratio was 1 . However, as shown in Fig. 2, it decreased sharply with increasing concentrations of precipitated iron when interstitial waters were processed. Elevated concentrations of dissolved iron in the interstitial water are common in many lakes. Frequently, highest concentrations are found at depths were labile iron oxyhydroxides are reduced. Similar or even greater dissolved iron concentrations than in Lac Tantaré have been reported from interstitial waters of other lakes (e.g. Belzile et al., 1990; Carignan and Nriagu, 1985; Carignan and Lean, 1991; Holdren and Bricker, 1977; Nembrini et al., 1982; Sakata, 1985; Peterson and Carpenter, 1986; Tessier et al., 1989; Wheeler and Giller, 1984; Weiler, 1973). Thus, the results presented in Fig. 2 suggest that [TDP] of interstitial waters could often be largely underestimated if the $\mathrm{P}$ associated with iron precipitate formed during digestion are not taken into account.

In order to test if the isotopic dilution method is quantitative, interstital water samples were spiked with $0.32 \mu \mathrm{mole} / 1$ and $0.64 \mu \mathrm{mole} / 1$ of phosphate prior to analysis; these spikes corresponded approximately to 30 and $60 \%$ respectively of the original [TDP]. Original and spiked samples were then labelled with ${ }^{32} \mathrm{P}$, and processed as described in the methods. As can be seen from Table 1, these spikes increased the $\left[\right.$ TDP $_{\text {cent }}$ ] concentration in the supernatant only by about $0.05 \mu \mathrm{mole} / \mathrm{l}$.

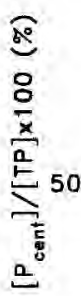

$$
y=\frac{100}{+0.019\{\mathrm{Fe}-0 \mathrm{x}\}}
$$

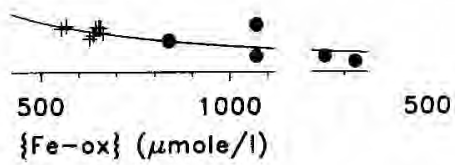

Figure 2. Ratios of $\left({ }^{32} \mathrm{P}_{\text {cent }}\right) /\left({ }^{32} \mathrm{P}_{\text {added }}\right)$ in relation to particulate iron concentration $\{\mathrm{Fe}-\mathrm{ox}\}$. Interstitial water samples were obtained from Lac Tantaré sediments:

(O) porewater 3 times diluted

$(\triangle)$ autoclaved sediment, porewater 3 times diluted

(口) Gamma irradiated sediment, porewater 3 times diluted

(-) sediment sterilized with $0.16 \%$ formaldehyde, porewater 3 times diluted

$(+)$ anoxic sediment, porewater not diluted 


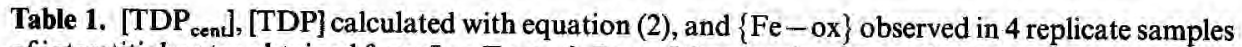
of interstitial water obtained from Lac Tantaré. Part of the samples were spiked with phosphate prior to digestion. n.m. $=$ not measured.

\begin{tabular}{lllll}
\hline $\begin{array}{l}\text { Sample } \\
\text { number }\end{array}$ & $\begin{array}{l}\text { spike } \\
(\mu \mathrm{mole} / \mathrm{l})\end{array}$ & $\begin{array}{l}{\left[\mathrm{TDP}_{\text {cenn }}\right]} \\
(\mu \mathrm{mole} / \mathrm{l})\end{array}$ & $\begin{array}{l}{[\mathrm{TDP}]} \\
(\mu \mathrm{mole} / \mathrm{l})\end{array}$ & $\begin{array}{l}\{\mathrm{Fe}-\mathrm{ox}\} \\
(\mu \mathrm{mole} / \mathrm{l})\end{array}$ \\
\hline & & 0.077 & 1.18 & n.m. \\
2 & & 0.077 & 0.99 & n.m. \\
3 & & 0.077 & 1.01 & n.m. \\
4 & & 0.087 & 1.15 & n.m. \\
$x \pm \mathrm{SD}$ & & $0.081 \pm 0.006$ & $1.08 \pm 0.1$ & \\
1 & 0.32 & 0.129 & 1.56 & 554 \\
2 & 0.32 & 0.129 & 1.41 & 654 \\
3 & 0.32 & 0.132 & 1.55 & 657 \\
4 & 0.32 & 0.087 & 1.25 & 639 \\
$x \pm \mathrm{SD}$ & & $0.119 \pm 0.022$ & $1.44 \pm 0.14$ & $625 \pm 49$ \\
1 & 0.64 & 0.139 & 1.80 & 568 \\
2 & 0.64 & 0.126 & 1.96 & 629 \\
3 & 0.64 & 0.135 & 1.80 & 664 \\
4 & 0.64 & 0.129 & 1.49 & 646 \\
$x \pm \mathrm{SD}$ & & $0.132 \pm 0.006$ & $1.76 \pm 0.20$ & $627 \pm 41$ \\
\hline
\end{tabular}

However, if [TDP] was calculated with eq (2), average [TDP] concentrations were $1.08 \mu \mathrm{mole} / \mathrm{l}, 1.44 \mu \mathrm{mole} / \mathrm{l}$, and $1.74 \mu \mathrm{mole} / \mathrm{l}$ in the original and spiked samples respectively. Thus, the method allows quantitative recovery of spiked phosphorus.

At the low $\mathrm{pH}$ value of 2.3 found at the end of the digestion, adsorption of dissolved inorganic phosphates on iron compounds having surface hydroxyl groups can be described, as (Stumm and Morgan, 1981):

$$
\equiv \mathrm{Fe}-\mathrm{OH}+\mathrm{H}_{2} \mathrm{PO}_{4}^{-} \stackrel{* \mathrm{~K}_{\mathrm{dds}}}{=} \equiv \mathrm{FeH}_{2} \mathrm{PO}_{4}+\mathrm{OH}^{-}
$$

with

$$
{ }^{*} \mathrm{~K}_{\mathrm{ads}}=\frac{\left\{\equiv \mathrm{FeH}_{2} \mathrm{PO}_{4}\right\}\left[\mathrm{OH}^{-}\right]}{\{\equiv \mathrm{Fe}-\mathrm{OH}\}\left[\mathrm{H}_{2} \mathrm{PO}_{4}^{-}\right]}
$$

where ${ }^{*} \mathrm{~K}_{\mathrm{ads}}$ is an apparent equilibrium constant; $\{\equiv \mathrm{Fe}-\mathrm{OH}\}$ and $\left\{\equiv \mathrm{FeH}_{2} \mathrm{PO}_{4}\right\}$ are the concentrations of free sites and of sites occupied by phosphate respectively. It should be noted that at the low $\mathrm{pH}$ value prevailing at the end of the digestion, the surface species $\equiv \mathrm{FeH}_{2} \mathrm{PO}_{4}$ should be dominant; at higher $\mathrm{pH}$ values other surface species should be considered for the adsorption of phosphates. The notation " $\equiv$ " refers to adsorption sites, whereas \{\} and [ ] refer to concentrations of the solid and dissolved species respectively. At low density of adsorption, the concentration of free sites is close to the concentration of total sites $\{\equiv \mathrm{Fe}-\mathrm{O}-\}_{\mathrm{T}}$. Thus the following 
approximation can be made:

$$
\equiv \mathrm{Fe}-\mathrm{OH}\}=\{\equiv \mathrm{Fe}-\mathrm{O}-\}_{\mathrm{T}}
$$

Concentrations of sites can be related to the concentration of the iron precipitate $\{\mathrm{Fe}-\mathrm{ox}\}$ and of phosphate adsorbed to the iron precipitate $\{\mathrm{Fe}-\mathrm{P}\}$ by the following equations:

$$
\begin{aligned}
& \equiv \mathrm{Fe}-\mathrm{O}-\}_{\mathbf{r}}=\mathrm{N} \cdot\{\mathrm{Fe}-\mathrm{ox}\} \\
& \left.\equiv \mathrm{FeH}_{2} \mathrm{PO}_{4}\right\}=\{\mathrm{Fe}-\mathrm{P}\}
\end{aligned}
$$

where $\mathrm{N}$ is the number of mole of adsorption sites per mole of iron precipitate. Substitution of (5)-(7) into (4) leads to

$$
\mathrm{K}_{\mathrm{ads}}=\frac{\mathrm{N}^{*} \mathrm{~K}_{\mathrm{ads}}}{\left[\mathrm{OH}^{-}\right]}=\frac{\{\mathrm{Fe}-\mathrm{P}\}}{\{\mathrm{Fe}-\mathrm{ox}\}\left[\mathrm{H}_{2} \mathrm{PO}_{4}^{-}\right]}
$$

where $\mathrm{K}_{\mathrm{ads}}$ is the apparent equilibrium constant at a given $\mathrm{pH}$ (e.g. that at the end of the oxidation with persulfate). At $\mathrm{pH} 2.3$, the ratio $\left[\mathrm{TDP}_{\text {cent }}\right] /[\mathrm{TP}]$ can thus be expressed:

$$
\frac{\left[\mathrm{TDP}_{\text {cent }}\right]}{[\mathrm{TP}]}=\frac{\left[\mathrm{H}_{3} \mathrm{PO}_{4}\right]+\left[\mathrm{H}_{2} \mathrm{PO}_{4}^{-}\right]}{\left[\mathrm{H}_{3} \mathrm{PO}_{4}\right]+\left[\mathrm{H}_{2} \mathrm{PO}_{4}^{-}\right]+\{\mathrm{Fe}-\mathrm{P}\}}
$$

Combining equation ( 8 ) and (9) leads to:

$$
\frac{\left[\mathrm{TDP}_{\text {cent }}\right]}{[\mathrm{TP}]}=\frac{}{1+\frac{\mathrm{K}_{\mathrm{ads}}\{\mathrm{Fe}-\mathrm{ox}\}}{\left[\mathrm{H}^{+}\right] / \mathrm{K}_{1}+1}}
$$

where $\mathrm{K}_{1}$ is the first acidity constant of $\mathrm{H}_{3} \mathrm{PO}_{4}$.

According to eq $(10)$ the ratio $\left[\mathrm{TDP}_{\text {cent }}\right] /[\mathrm{TP}]$, which equals $\left({ }^{32} \mathrm{P}_{\text {cent }}\right) /\left({ }^{32} \mathrm{P}_{\text {added }}\right)$ (see eq 2 ) decreases with increasing $\{\mathrm{Fe}-\mathrm{ox}\}$. The experimental data are best fitted by equation (10) for $\mathrm{K}_{\mathrm{ads}} /\left(\left[\mathrm{H}^{+}\right] / \mathrm{K}_{1}+1\right)=0.0191 / \mu$ mole (see Fig. 2 ). The sorption model describes adequately the sorption of phosphorus on the iron precipitate formed during persulfate digestion of Lac Tantaré porewaters. In case results from other interstitial waters confirm this model, then [TDP] could be determined without labelling the samples with ${ }^{32} \mathrm{P}$ by solving eq (10) for [TDP]:

$$
[\mathrm{TDP}]=\left[\mathrm{TDP}_{\text {cent }}\right]\left(1+\frac{\mathrm{K}_{\mathrm{ads}}\{\mathrm{Fe}-\mathrm{ox}\}}{\left[\mathrm{H}^{+}\right] / \mathrm{K}_{1}+1}\right)
$$

Low dissolved phosphorus concentrations and high iron concentrations in interstitial waters could conceivably lead to undetectable levels of [TDP ${ }_{\text {cent }}$ ] whose value is required to calculate [TDP] with equation (2). This difficulty can be overcome by 
spiking the porewater sample with a known amount of $\mathrm{P}$, sufficient to raise [TDP ${ }_{\text {cent }}$ ] to a measurable level. The [TDP] concentration of the original sample can then be obtained by subtracting the spike from the measured [TDP] concentration since spike recovery has been demonstrated.

In summary, these results show that in samples rich in dissolved iron precipitates of iron oxyhydroxides, formed during digestion, strongly adsorb orthophosphate and hence cause a significant underestimation of TDP concentrations. Figure 2 suggests that important losses of $\mathrm{P}$ can be experienced when the Fe concentration exceeds the TDP concentration and the precipitated iron concentration exceeds $100 \mu \mathrm{mole} / \mathrm{L}$. The isotopic dilution method described allows to correct for these losses.

\section{ACKNOWLEDGEMENT}

We are obliged to L. Sigg, J. S. Meyer and P. Van Cappellen for critical reading of the manuscript. R. Gächter thanks the professors, students and staff of INRS-Eau for their hospitality and, particularly, acknowledges the assistance of S. St-Pierre.

\section{REFERENCES}

Belzile, N. and A. Tessier, 1990. Interactions between arsenic and iron oxyhydroxides in lacustrine sediments. Geochim. Cosmochim. Acta. 54:103-109.

Boers, P. C. M., O. van Hese, F. de Bles, and Th. E. Cappenberg, 1985. The release of dissolved organic phosphorus from the peaty sediments of the shallow eutrophic Loosdrecht Lakes (The Netherlands). 3rd Internat. Symposium. Interactions Between Sediments and Waters. Geneva August 1984.

Carignan, R., 1988. Seasonal dynamics of sulfate and hydrogen sulfide near the sediment-water interface of an oligotrophic acid lake. Verh. Internat. Verein. Limnol., 23:106-115.

Carignan, R. and J.O. Nriagu, 1985. Trace metal deposition and mobility in the sediments of two lakes near Sudbury, Ontario. Geochim. Cosmochim. Acta. 49:1753-1764.

Carignan, R. and D. R.S. Lean, 1991. Regeneration of dissolved substances in a seasonally anoxic lake: The relative importance of processes occuring in the water column and in the sediments. Limnol. Oceanogr. (in press).

Chapman, B. M., D. R. Jones, and R. F. Jung, 1983. Processes controlling metal ion attenuation in acid mine drainage streams. Geochim. Cosmochim. Acta, 47:1957-1973.

Enell, M. and S. Löfgren, 1987. Phosphorus in Interstitial water: Methods and dynamics. Hydrobiologia, 170:103-132.

Hesslein, R. H., 1976. An in situ sampler for close interval pore water studies. Limnol. Oceanogr. 21:912-914.

Holdren, G. C. Jr and D. E. Armstrong, 1980. Factors affecting phosphorus release from intact lake sediment cores. Environ. Sci. Technol., 14:79-87.

Holdren, G. R. Jr. and O.P. Bricker, 1977. Distribution and Control of dissolved iron and manganese in the interstitial waters of the Chesapeake Bay. Biological Implications of Metals in the Environment. Proc. of the 15th. Ann. Hanford Life Symp. 1975. Conf. 750929, ERDA Symp. Ser. 178-196.

Löfgren, S., 1987. P retention in sediments. Implications for aerobic phosphorus release in shallow lakes. PhD dissertation Uppsala University. ISBN 91-554-2079-6.

Nembrini, G., J. A. Capobianco, J. Garcia, and J.-M. Jacquet, 1982. Interaction between interstitial water and sediment in two cores of Lac Léman. Switzerland. Hydrobiologia. 92:363-375.

Ostrofsky, M. L., D. A. Osborne, and T. J. Zebulske, 1989. Relationship between anaerobic phosphorus release rates and sedimentary phosphorus species. Can. J. Fish. Aquat. Sci. 46:416419. 
Peterson, M. L. and R. Carpenter, 1986. Arsenic distributions in pore waters and sediments of Puget Sound, Lake Washington coast and Saanich Inlet, B.C. Geochim. Cosmochim. Acta. 50:353369.

Sakata, M., 1985. Diagenetic remobilization of manganese, iron, copper and lead in anoxic sediment of a fresh water pond. Water. Res. 19:1033-1038.

Sondergaard, M., 1989. Phosphorus release from hypertrophic lake sediment: Experiments with intact sediment cores in a continuous flow system. Arch. Hydrobiol., 116:45-59.

Stauffer, R. and D.E. Armstrong, 1986. Cycling of iron, manganese, phosphorus, calcium and potassium in two stratified bassins of Shaawa Lake., Minnesota. Geochim. Cosmochim. Acta, $50: 215-229$.

Stumm, W. and J.J. Morgan, 1981. Aquatic chemistry. An Introduction Emphasizing Chemical Equilibria in Natural Waters. 2nd Edition. Wiley and Sons, New York, $780 \mathrm{p}$.

Tessier, A., R. Carignan, B. Dubreuil, and F. Rapin, 1989. Partitioning of zinc between the water column and the oxic sediments in lakes. Geochim. Cosmochim. Acta. 53:1511-1522.

Vogler, P., 1965. Fortschritte Wasserchem. u. Grenzgeb., 2:109-119.

Wheeler, B.D. and K.E. Giller, 1984. The use of dialysis cells for investigating pore water composition in wetland substrata, with particular reference to dissolved iron and sulfide. Commun. in Soil Sci. Plant. Anal., 15:707-716.

Weiler, R.R., 1973. The interstitial water composition in the sediments of the Great Lakes. I. Western Lake Ontario. Limnol. Oceanogr. 18:918-931.

Received 26 March 1991

accepted 28 June 1991. 